\title{
ANALISIS PERBANDINGAN KINERJA KEUANGAN PEMERINTAH DAERAH YANG MEMPEROLEH OPINI WAJAR TANPA PENGECUALIAN (WTP) DI PROVINSI NUSA TENGGARA BARAT
}

\author{
Nurabiah \\ Jurusan Akuntansi FEB Unram \\ nurabiah@unram.ac.id
}

\begin{abstract}
The purpose of this study is to analyze the comparison financial performance of local government that has WTP Opinion in West Nusa Tenggara Province during 2016. The population of this study are 10 local government that have WTP Opinion Opinion in West Nusa Tenggara Province and the data used in this study is a secondary data. Analysis using Financial Ratio that consist of ratio of Regional Independence, Effectiveness ratio, Efficiency ratio, Activity ratio, and Growth ratio. The results showed that financial performance between local government that has WTP Opinion shows different ratios so that the level of performance is also different.
\end{abstract}

Keywords : Local Financial Performance, WTP Opinion

\begin{abstract}
Abstrak
Tujuan dari penelitian ini untuk menganalisa perbandingan kinerja keuangan pemerintah daerah yang memperoleh opini WTP di Nusa Tenggara Barat selama tahun 2016. Populasi dari penelitian ini 10 pemerintah daerah yang memperoleh opini WTP di provinsi Nusa Tenggara Barat dan data yang digunakan yaitu data sekunder. Analisis yang digunakan adalah rasio keuangan yang terdiri dari rasio kemandirian daerah, rasio efektivitas, rasio efisiensi, rasio keselaran, dan rasio pertumbuhan. Hasil penelitian menunjukkan bahwa kinerja keuangan antara pemerintah daerah yang memiliki Opini WTP menunjukkan rasio yang berbeda sehingga tingkat kinerjanya juga berbeda.
\end{abstract}

Kata Kunci : Kinerja pemerintah daerah, opini WTP 
Nurabiah: Analisis Perbandingan Kinerja Keuangan Pemerintah Daerah...

\section{PENDAHULUAN}

Otonomi Daerah merupakan isu strategis konsep pembangunan ekonomi berbasis Desentralisasi di Indonesia. Tujuan yang paling penting dan kebijakan otonomi daerah ini adalah untuk memberi wewenang yang lebih luas kepada pemerintah daerah terutama dalam mengatur pembangunan daerahnya sendiri. 1 Januari tahun 2001 merupakan awal diberlakukannya kebijakan Otonomi daerah, pemberian otonomi yang luas membuka jalan bagi pemerintah daerah untuk melakukan pembaharuan dalam sistem pengelolaan keuangan daerah dan anggaran daerah. Untuk itu setiap daerah dituntut agar dapat membiayai daerahnya sendiri melalui sumber-sumber keuangan yang dimilikinya (Fattah dan Irman 2010).

Kemampuan daerah dalam menggali dan mengembangkan potensi daerah yang dimilikinya sebagai sumber pendapatan daerah akan sangat menentukan keberhasilan kebijakan otonomi daerah tersebut. Keseriusan pemerintah Indonesia mengenai otonomi daerah diwujudkan dengan dihasilkannya UU No. 22 tahun 1999 yang telah diganti dengan UU No. 32 tahun 2004 mengenai pembagian kewenangan di pemerintah daerah, dan UU No. 25 tahun 1999 yang telah diganti dengan UU No. 33 mengenai Pembagian Keuangan antara Pusat dan Daerah. Undang-undang tersebut telah dijadikan 
sebagai aturan umum dalam implementasi kebijakan otonomi daerah di seluruh Indonesia. Oleh karena itu, otonomi daerah diharapkan bisa menjadi jembatan bagi pemerintah daerah untuk mendorong efisiensi ekonomi, efisiensi pelayanan publik sehingga mampu mendorong pertumbuhan ekonomi daerah serta meningkatkan kesejahteraan penduduk lokal melalui berbagai efek multiplier dari desentralisasi yang diharapkan bisa terwujud (Khusaini 2006). Selain itu pemerintah daerah dituntut untuk dilakukan secara transparansi dalam memberikan informasi, partisipatif untuk terlibat, dan memiliki akuntabiltas yang tinggi.

Menurut Astuty dan Fanida (2012) akuntabilitas meliputi pemberian informasi keuangan kepada masyarakat dan pengguna lainnya sehingga memungkinkan bagi mereka untuk menilai pertanggungjawaban pemerintah atas semua aktifitas yang dilakukan, bukan hanya laporan keuangan saja namun harus memberikan informasi dalam pembuatan keputusan ekonomi, sosial dan politik. Akuntabilitas diharapkan dapat memperbaiki kualitas serta kinerja dari instansi pemerintah agar menjadi pemerintahan yang transparan dan berorientasi pada kepentingan publik.

Akuntabilitas pengelolaan dan pertanggungjawaban keuangan saat ini telah menjadi salah satu indikator kinerja pemerintah daerah. Opini Wajar Tanpa Pengecualian (WTP) menjadi tujuan dalam pengelolaan keuangan publik 
Nurabiah: Analisis Perbandingan Kinerja Keuangan Pemerintah Daerah...

sebagai tuntutan reformasi birokrasi. Opini WTP menjadi salah satu indikator yang mencerminkan keberhasilan reformasi birokrasi pada pemerintah daerah bersangkutan. Akuntabilitas dan transparansi menjadi budaya tanggung jawab penggunaan anggaran negara yang perlu terus dikembangkan sebagai bentuk pertanggungjawaban public kepada masyarakat luas. Laporan keuangan yang dibuat oleh pemerintah pusat dan pemerintah daerah merupakan gambaran akuntabilitas penggunaan dana yang berasal dari anggaran negara, dengan semakin baik dan bertanggung jawab dalam penggunaannya, maka BPK akan memberikan suatu opini terhadap laporan keuangan yang diperiksa (Firmanzah 2012).

Untuk mengetahui kinerja keuangan Pemerintah Kabupaten/Kota yang telah memperoleh opini WTP, WDP, dan TW,TMP, maka dilakukan suatu analisis terhadap kinerja keuangan pemerintah daerah dalam pengelolaan keuangan daerahnya. Salah satu alat untuk menganalisis kinerja pemerintah daerah dalam mengelola keuangan daerahnya adalah dengan melakukan analisis rasio keuangan terhadap APBD yang telah ditetapkan dan dilaksanakan (Halim 2004). Penggunaan analisis rasio laporan keuangan sebagai alat analisis keuangan secara luas sudah diterapkan pada lembaga perusahaan yang bersifat komersial, sedangkan pada lembaga publik khususnya pemerintah daerah masih sangat terbatas. Dengan analisis rasio laporan keuangan 
pemerintah daerah dapat diketahui bagaimana kinerja pemerintah daerah yang bersangkutan dan juga dapat dijadikan sebagai acuan untuk lebih meningkatkan kinerja pemerintah daerah.

Hasil analisis rasio keuangan ini selanjutnya digunakan untuk tolak ukur untuk menilai kemandirian keuangan daerah dalam membiayai penyelenggaraan otonomi daerah, mengukur efektifitas dalam merealisasikan pendapatan asli daerah, mengukur efisiensi dalam melakukan pengeluaran yang dibelanjakan sesuai dengan peruntukkannya dan memenuhi dari apa yang direncanakan, mengukur sejauh mana aktifitas pemerintah dalam membelanjakan pendapatan daerahnya untuk belanja modal, dan mengetahui seberapa besar kontribusi penerimaan komponen dalam pendapatan asli daerah dari pajak daerah dan retribusi daerah. Sehingga diharapkan dapat meningkatkan pendapatan daerah (Susantih dan Seftiana 2009).

Badan Pemeriksa Keuangan (BPK) Perwakilan Provinsi Nusa Tenggara Barat menyerahkan Laporan Hasil Pemeriksaan (LHP) atas Laporan Keuangan Pemerintah Daerah Tahun Angaran 2016 pada sepuluh pemerintah daerah, yaitu Pemerintah Kabupaten Bima, Kabupaten Dompu, Kabupaten Lombok Barat, Kabupaten Lombok Tengah, Kabupaten Lombok Timur, Kabupaten Lombok Utara, Kabupaten Sumbawa, Kabupaten Sumbawa Barat, Kota Bima, dan Kota Mataram. Sepuluh entitas ini seluruhnya memperoleh Opini Wajar 
Nurabiah: Analisis Perbandingan Kinerja Keuangan Pemerintah Daerah...

Tanpa Pengecualian (WTP). NTB merupakan provinsi ketiga di Indonesia Timur yang masuk dalam wilayah kewenangan anggota BPK VI yang memperoleh prestasi 100 persen WTP dari 11 entitas termasuk Provinsi. Pertama adalah Provinsi Gorontalo dan kedua Provinsi Kalimantan Selatan. Pihaknya mengapresiasi indeks pembangunan manusia Provinsi NTB tahun 2016 sebesar 65,81 mengalami peningkatan meskipun masih di bawah IPM nasional sebesar 70,18. Dan berharap kedepan, IPM NTB lebih baik dari rata-rata nasional karena pencapaian opini WTP tidak memiliki makna, jika kesejahteraan rakyat tidak terwujud.

Berdasarkan data opini 10 pemerintah daerah yang memperoleh opini WTP untuk Tahun Anggaran 2016 tentunya mengalami perbedaan kinerja keuangan. Menurut Suaedy (2011) pemberian opini WTP terhadap laporan keuangan adalah sebuah apresiasi dari BPK terhadap instansi pemerintah yang telah melakukan pengelolaan keuangan dengan baik. Namun demikian, tidak selamanya entitas pemerintah daerah yang memperoleh Opini Wajar Tanpa Pengecualian dari BPK pada tahun anggaran tertentu juga memiliki kinerja keuangan yang baik dari entitas pemerintah daerah yang memperoleh opini non-WTP. Untuk mengetahui kinerja keuangan Pemerintah Kabupaten/Kota yang telah memperoleh opini WTP, WDP, dan TW,TMP, maka dilakukan suatu analisis terhadap kinerja keuangan pemerintah daerah dalam pengelolaan 
keuangan daerahnya. Salah satu alat untuk menganalisis kinerja pemerintah daerah dalam mengelola keuangan daerahnya adalah dengan melakukan analisis rasio keuangan terhadap APBD yang telah ditetapkan dan dilaksanakan (Halim 2004).

Penggunaan analisis rasio laporan keuangan sebagai alat analisis keuangan secara luas sudah diterapkan pada lembaga perusahaan yang bersifat komersial, sedangkan pada lembaga publik khususnya pemerintah daerah masih sangat terbatas. Dengan analisis rasio laporan keuangan pemerintah daerah dapat diketahui bagaimana kinerja pemerintah daerah yang bersangkutan dan juga dapat dijadikan sebagai acuan untuk lebih meningkatkan kinerja pemerintah daerah. Hasil analisis rasio keuangan ini selanjutnya digunakan untuk tolak ukur untuk menilai kemandirian keuangan daerah dalam membiayai penyelenggaraan otonomi daerah, mengukur efektifitas dalam merealisasikan pendapatan asli daerah, mengukur efisiensi dalam melakukan pengeluaran yang dibelanjakan sesuai dengan peruntukkannya dan memenuhi dari apa yang direncanakan, mengukur sejauh mana aktifitas pemerintah dalam membelanjakan pendapatan daerahnya untuk belanja modal, dan mengetahui seberapa besar kontribusi penerimaan komponen dalam pendapatan asli daerah dari pajak daerah dan retribusi daerah. Sehingga diharapkan dapat meningkatkan pendapatan daerah 
Nurabiah: Analisis Perbandingan Kinerja Keuangan Pemerintah Daerah...

(Susantih 2009). Oleh karena itu penelitian ini bertujuan untuk menganalisis perbandingan kinerja keuangan antar pemerintah daerah yang memperoleh Opini Wajar Tanpa Pengecualian di Provinsi NusaTenggara Barat.

\section{LANDASAN TEORI}

\section{Penelitian Terdahulu}

Ada beberapa kajian penelitian terdahulu yang berhubungan dengan penelitian ini, antara lain : 1) Wibawa, dkk (2017) menyatakan bahwa rasio kemandirian keuangan daerah masing-masing masih rendah atau instruktif; rasio efektifitas keuangan daerah masing-masing sangat efektif ; rasio efisiensi keuangan daerah yang memperoleh WTP kurang efisien, sedangkan yang memperoleh WDP cukup efisien ; rasio keserasian keuangan daerah masingmasing lebih memprioritaskan pada belanja operasi dibanding belanja modal ; dan rasio pertumbuhan Pendapatan Asli Daerah (PAD) masing-masing masih mengalami tren pertumbuhan yang fluktuatif. 2) Taufik (2017) menyatakan bahwa kinerja keuangan pemerintah daerah periode opini WTP dan WDP tidak lebih dan tidak berbeda dengan kinerja keuangan pemerintah daerah periode opini TW dan TMP, yang diukur dengan empat indicator yaitu rasio kemandirian, rasio efektivitas, rasio efisiensi, dan rasio aktivitas pada 
kabupaten/kota se-Sumatera tahun 2007-2011, serta kinerja keuangan Induk tidak lebih dan tidak berbeda dengan kinerja keuangan pemerintah daerah Anak/Pemekaran.3) Patra dan Ramlah (2017) menyatakan bahwa ada hubungan positif dan logis antara kinerja pengelola keuangan daerah dengan opini laporan hasil pemeriksaan BPK. Pempinan SKPD dalam melaksanakan tugas pokok, visi dan misi-nya tidak terlalu focus dan berorientasi bagaimana memperoleh opini WDP atau WTP, tetapi yang terpenting adalah bagaimana meningkatkan kinerja pengelolaan keuangan daerah, karena dengan kinerja yang baik, akan menjadi peluang atau potensi bagi pemerintah daerah untuk memperoleh Opini yang baik (WDP, WTP) dari pihak Auditor. 4) Hakiki (2017) menyatakan bahwa tidak terdapat perbedaan kinerja keuangan kriteria ekonomis dan efisiensi antara pemerintah daerah kota/kabupaten yang memperoleh opini WTP dan non WTP dan terdapat perbedaan kinerja keuangan kriteria efektivitas antara pemerintah daerah kota/kabupaten yang memperoleh opini WTP dan non WTP. Namun demikian tingkat kinerja keuangan pemerintah daerah yang memperoleh opini WTP tidak selalu memiliki kinerja yang baik, dari hasil penelitian 51 didapatkan bahwa LKPD yang memperoleh opini Non WTP ternyata lebih baik dari LKPD yang memperoleh opini WTP. 5) Tarmizi, Khairudin, dan Jayadi (2014) menyatakan bahwa Kinerja Keuangan Pemerintah Daerah Kota Bandar Lampung setelah 
Nurabiah: Analisis Perbandingan Kinerja Keuangan Pemerintah Daerah...

Opini WTP berbeda dengan sebelum Opini WTP yang artinya Kinerja Keuangan Pemerintah Daerah Kota Bandar Lampung setelah Opini WTP lebih baik sebelum Opini WTP tahun anggaran 2008 - 2012. 6) Khairudin (2013) menyatakan bahwa kinerja keuangan Pemerintah Kabupaten/Kota seIndonesia yang beropini WTP berbeda dan lebih baik tidak lebih baik dengan yang menerima non_WTP tahun anggaran 2011. Kemandirian keuangan Pemerintah Kabupaten/Kota se-Indonesia yang beropini WTP secara prosentase lebih tinggi sebesar $2,73 \%$ dari Pemerintah Kabupaten/Kota seIndonesia yang beropini non_WTP; efektifitas keuangan Pemerintah Kabupaten/Kota se-Indonesia yang beropini WTP secara prosentase lebih tinggi sebesar 4,62\% dari Pemerintah Kabupaten/Kota se-Indonesia yang beropini non_WTP; efisiensi keuangan Pemerintah Kabupaten/Kota seIndonesia yang beropini WTP secara prosentase lebih tinggi sebesar 0,54\% dari Pemerintah Kabupaten/Kota se-Indonesia yang beropini non_WTP; dan pertumbuhan keuangan Pemerintah Kabupaten/Kota seIndonesia yang beropini WTP secara prosentase lebih tinggi sebesar 5,09\% dari Pemerintah Kabupaten/Kota se-Indonesia yang beropini non_WTP. Walaupun secara persentase pebedaannya tidak telalu besar, namun hasil pengujian statistika menunjukkan perbedaan yang signifikan. 


\section{Kinerja Keuangan Daerah}

Kinerja adalah gambaran mengenai tingkat pencapaian pelaksanaan suatu kegiatan /program/kebijakan dalam mewujudkan sasaran, tujuan, misi dan visi organisasi yang tertuang dalam strategic planning suatu organisasi. (Mahsun 2012:25). Sedangkan keuangan daerah memiliki ruang lingkup yang terdiri atas keuangan yang dikelola langsung dan kekayaan daerah yang dipisahkan. Yang termasuk keuangan daerah yang dikelola langsung adalah APBD dan barang-barang inventaris milik daerah. Di lain pihak, keuangan daerah yang dipisahkan meliputi BUMD (Badan Usaha Milik Daerah). (Halim 2007:25). Jadi dapat disimpulkan bahwa kinerja keuangan daerah yaitu tingkat pencapaian pelaksanaan suatu kegiatan /program/kebijakan di bidang keuangan yang dikelola langsung adalah APBD dan barang-barang inventaris milik daerah dalam mewujudkan sasaran, tujuan, misi dan visi daerah yang tertuang dalam strategic planning suatu daerah tersebut.

\section{Ukuran Kinerja Keuangan Daerah}

Salah satu alat untuk menilai Kinerja keuangan Pemerintah Daerah dalam mengelola keuangan daerahnya adalah dengan Analisis Rasio terhadap Anggaran Pemerintah Daerah yang telah ditetapkan dan dilaksanakan. Dalam praktek ada beberapa teknik analisis laporan keuangan yang bisa diterapkan untuk mendapatkan informasi yang diharapkan antara lain (Marsudi 2002) a). 
Nurabiah: Analisis Perbandingan Kinerja Keuangan Pemerintah Daerah...

Analisis Varians (selisih). b). Analisis Rasio Keuangan. c). Analisis pertumbuhan, d).Analisis regresi , e).Analisis Prediksi.

Menurut (Halim 2004) beberapa rasio yang dapat dikembangkan berdasarkan data keuangan yang bersumber dari APBD yaitu Rasio kemandirian daerah, Rasio Efisiensi dan Efektifitas, Rasio Keserasian Keuangan Daerah, dan Rasio Pertumbuhan Keuangan Daerah.

a) Rasio Kemandirian Keuangan Daerah

Rasio kemandirian adalah rasio yang menunjukan Pemerintah Daerah dalam membiayai sendiri kegiatan pemerintah, pembangunan pelayanan kepada masyarakat yang telah membayar pajak dan retribusi daerah sebagai sumber Pendapatan Asli Daerah dibandingkan dengan pendapatan daerah yang berasal dari sumber lain, misalnya bantuan Pemerintah Pusat atau pinjaman. Semakin tinggi hasilnya, berarti semakin tiggi tingkat kemandirian suatu daerah, yang berarti juga bahwa ketergantungan akan bantuan dari pemerintah pusat semakin rendah. Penjelasan pola hubungan dan tingkat kemampuan daerah dapat dilihat pada tabel 1 berikut : 
Tabel 1.

Kriteria Rasio Kemandirian Daerah

\begin{tabular}{ccc}
\hline $\begin{array}{c}\text { Kemampuan } \\
\text { Keuangan }\end{array}$ & Kemandirian (\%) & Pola Hubungan \\
\hline Rendah Sekali & $0 \%-25 \%$ & Instruktif \\
Rendah & $25 \%-50 \%$ & Konsultatif \\
Sedang & $50 \%-75 \%$ & Partisipatif \\
Tinggi & $75 \%-100 \%$ & Delegatif
\end{tabular}

Sumber : Halim (2007:232)

b) Rasio Efektifitas Keuangan Daerah

Rasio Efektivitas menggambarkan seberapa efektif suatu daerah dalam merealisasikan PAD yang telah dianggarkan tersebut. Kinerja keuangan pemerintah daerah dikategorikan efektif apabila rasio lebih dari 1 atau 100\%. Berikut ini kriteria rasio efektifitas dikategorikan sebagai berikut:

Tabel 2.

Kriteria Rasio Efektifitas Kinerja Keuangan Daerah

\begin{tabular}{cc}
\hline Kriteria & Persentase Kinerja Keuangan (\%) \\
\hline Sangat Efektif & Diatas $100 \%$ \\
Efektif & $100 \%$ \\
Cukup Efektif & $90 \%-99 \%$ \\
Kurang Efektif & $75 \%-89 \%$ \\
Tidak Efektif & Dibawah $75 \%$ \\
\hline
\end{tabular}

Sumber : Mahmudi (2010:143) 
Nurabiah: Analisis Perbandingan Kinerja Keuangan Pemerintah Daerah...

c) Rasio Efisiensi Keuangan Daerah

Rasio Efisiensi adalah rasio yang menggambarkan perbandingan antara realisasi pengeluaran (belanja daerah) dengan realisasi pendapatan daerah (Halim, 2007:234). Kinerja pemerintah daerah dapat dikategorikan efisien apabila rasio yang dicapai kurang dari satu atau dibawah 100\%. Semakin kecil rasio efisiensi berarti kinerja pemerintah daerah semakin baik. Kriteria penilaian rasio efisiensi dapat dilihat pada tabel 3 berikut:

Tabel 3.

Kriteria Rasio Efisiensi Kinerja Keuangan Daerah

\begin{tabular}{cc}
\hline Kriteria & Persentase Kinerja Keuangan (\%) \\
\hline Sangat Efisien & Dibawah 60\% \\
Efisien & $60 \%-80 \%$ \\
Cukup Efisien & $80 \%-90 \%$ \\
Kurang Efisien & $90 \%-100 \%$ \\
Tidak Efisien & Diatas $100 \%$ \\
\hline
\end{tabular}

Sumber : Halim (2007:235)

d) Rasio Keserasian Keuangan Daerah

Rasio keserasian menggambarkan bagaimana pemerintah daerah memprioritaskan alokasi dananya pada belanja operasi dan belanja modal secara optimal. Semakin tinggi persentase dana yang dialokasikan untuk belanja operasi berarti persentase belanja yang digunakan untuk menyediakan sarana dan prasarana ekonomi masyarakat cenderung semakin kecil (Halim 
2007:236). Ada dua perhitungan dalam rasio keserasian ini, yaitu: Rasio Belanja Operasi dan Rasio Belanja Modal.

Rasio Belanja Operasi merupakan perbandingan antara total Belanja Operasi dengan Total Belanja Daerah. Rasio ini menginformasikan kepada pembaca laporan mengenai porsi belanja daerah yang dialokasikan untuk Belanja Operasi. Belanja Operasi merupakan belanja yang manfaatnya habis dikonsumsi dalam satu tahun anggaran, sehingga sifatnya jangka pendek dan dalam hal tertentu sifatnya rutin atau berulang. Pada umumya proporsi Belanja Operasi mendominasi total belanja daerah, yaitu antara $60-90 \%$. Pemerintah daerah dengan tingkat pendapatan yang tinggi cenderung memiliki porsi belanja operasi yang lebih tinggi dibandingkan pemerintah daerah yang tingkat pendapatannya rendah (Mahmudi 2010:164).

Rasio Belanja Modal merupakan perbandingan antara total realisasi belanja modal dengan total belanja daerah. Berdasarkan rasio ini, pembaca laporan dapat mengetahui porsi belanja daerah yang dialokasikan untuk investasi dengan bentuk belanja modal pada tahun anggaran bersangkutan. Belanja modal memberikan manfaat jangka menengah dan panjang juga bersifat rutin. Pada umumnya proporsi belanja modal dengan belanja daerah antara 5-20\% (Mahmudi 2010:164).

e) Rasio Pertumbuhan Keuangan Daerah 
Nurabiah: Analisis Perbandingan Kinerja Keuangan Pemerintah Daerah...

Rasio pertumbuhan digunakan untuk mengukur seberapa besar kemampuan pemerintah daerah dalam mempertahankan dan meningkatkan keberhasilannya yang telah dicapai dari periode ke periode berikutnya (Mahmudi 2010:138)

\section{Opini Audit}

Berdasarkan Undang-Undang Nomor 15 Tahun 2004 tentang Pemeriksaan Pengelolaan dan Tanggung Jawab Keuangan Negara, disebutkan bahwa terdapat empat (4) jenis opini audit yang diberikan oleh Badan Pemeriksa Keuangan (BPK) atas hasil pemeriksaan Laporan Keuangan Pemerintah (LKP). Masing-masing opini tersebut sebagai berikut:

a) Opini Wajar Tanpa Pengecualian (Unqualified Opinion)

Opini wajar tanpa pengecualian (Unqualified Opinion) adalah opini yang menyatakan bahwa laporan keuangan entitas yang diperiksa, menyajikan secara wajar dalam semua hal yang material dan sesuai dengan prinsip akuntansi yang berlaku umum di Indonesia. Mahmudi (2006) menjelaskan bahwa "opini yang paling baik adalah wajar tanpa pengecualian (unqualified opinion)". Opini wajar tanpa pengecualian diberikan karena auditor meyakini bahwa laporan keuangan telah bebas dari kesalahan-kesalahan atau kekeliruan yang material. Keyakinan auditor tersebut berdasarkan bukti-bukti audit yang dikumpulkan. 
b) Opini Wajar Dengan Pengecualian (Qualified Opinion)

Opini wajar dengan pengecualian menunjukan bahwa sebagian besar pos dalam laporan keuangan, posisi keuangan, hasil usaha, dan arus kas entitas tersebut telah disajikan secara wajar terbebas dari salah saji mateerial dan sesuai dengan prinsip akuntansi yang berlaku umum di Indonesia, kecuali untuk dampak hal-hal yang berhubungan dengan yang dikecualikan atau untuk pos-pos tertentu disajikan secara tidak wajar.

c) Opini Tidak Wajar (Adverse Opinion)

Opini tidak wajar adalah opini yang menyatakan bahwa laporan keuangan entitas yang diperiksa tidak menyajikan secara wajar posisi keuangan, hasil usaha, dan arus kas entitas tertentu sesuai dengan prinsip akuntansi yang berlaku umum di Indonesia. Keadaan seperti ini bisa terjadi karena buruknya sistem pengendalian internal dan sistem akuntansi yang ada. d) Peryataan Menolak Memberikan Opini (Disclaimer)

Pernyataan menolak memberikan opini adalah opini yang menyatakan bahwa auditor tidak menyatakan pendapat atas laporan keuangan yang menjelaskan bahwa auditor tidak dapat menyatakan pendapat atas hasil audit laporan keuangan karena dua alasan, yaitu auditor tergangganggu independensinya dan auditor dibatasi untuk mengakses data tertentu. (Mahmudi 2007). 
Nurabiah: Analisis Perbandingan Kinerja Keuangan Pemerintah Daerah...

\section{METODE PENELITIAN}

\section{Jenis Penelitian}

Jenis penelitian yang digunakan dalam penelitian ini adalah penelitian deskriptif dengan pendekatan kuantitatif. Penelitian deskriptif adalah bentuk atau model penelitian yang dilakukan untuk mengetahui nilai/melukiskan/ menggambarkan suatu variabel mandiri. Variabel mandiri yang dimaksud bisa satu atau lebih. Tanpa membandingkan atau menghubungkan dengan variabel atau sampel yang lain (Supriyanto 2009:117).

\section{Populasi dan Sampel}

\section{Populasi}

Menurut Sugiyono (2014:115) populasi adalah wilayah generalisasi yang terdiri atas obyek/subyek yang mempunyai kualitas dan karakteristik tertentu yang ditetapkan oleh peneliti untuk dipelajari dan kemudian ditarik kesimpulannya. Populasi dalam penelitian ini adalah seluruh kabupaten kota yang berada di wilayah Povinsi Nusa Tenggara Barat

\section{Sampel}

Menurut Sugiyono (2014:116) sampel adalah bagian dari jumlah dan karakteristik yang dimiliki oleh populasi tersebut. Sampel dalam penelitian ini Sampel dari penelitian ini dipilih dengan metode nonprobability sampling 
dengan teknik purposive sampling, yaitu sampel dipilih dengan pertimbangan tertentu (Sugiyono 2014:122). Tujuan menggunakan purposive sampling adalah agar hasil yang diperoleh lebih representative. Populasi dan sampel yang digunakan dalam penelitian ini memiliki kreteria yaitu :

1. Seluruh kabupaten/kota di provinsi Nusa Tenggara Barat

2. Kabupaten/Kota yang memperoleh WTP tahun 2016

Sehingga dapat disimpulkan jumlah sampel dalam penelitian ini yaitu ada 10 kabupaten/kota yang memperoleh WTP

\section{Teknik Pengumpulan Data}

Metode pengumpulan data yang dilakukan dalam penelitian ini yaitu dengan pencarian data sekunder, kemudian mengumpulkan data dengan cara mempelajari catatan-catatan dan dokumen-dokumen yang ada pada perusahaan atau instansi yang diteliti dengan menggunakan metode dokumentasi. Metode dokumentasi dilakukan dengan memperoleh data dari BPKP-RI Perwakilan Provinsi Nusa Tenggara Barat. Data yang diperoleh yaitu Laporan Hasil Pemeriksaan BPK-RI Perwakilan Sulawesi Tenggara atas Laporan Keuangan Pemerintah Daerah Tahun Anggaran 2016. 
Nurabiah: Analisis Perbandingan Kinerja Keuangan Pemerintah Daerah...

\section{Instrumen Penelitian}

Tabel 4.

Instrumen Penelitian

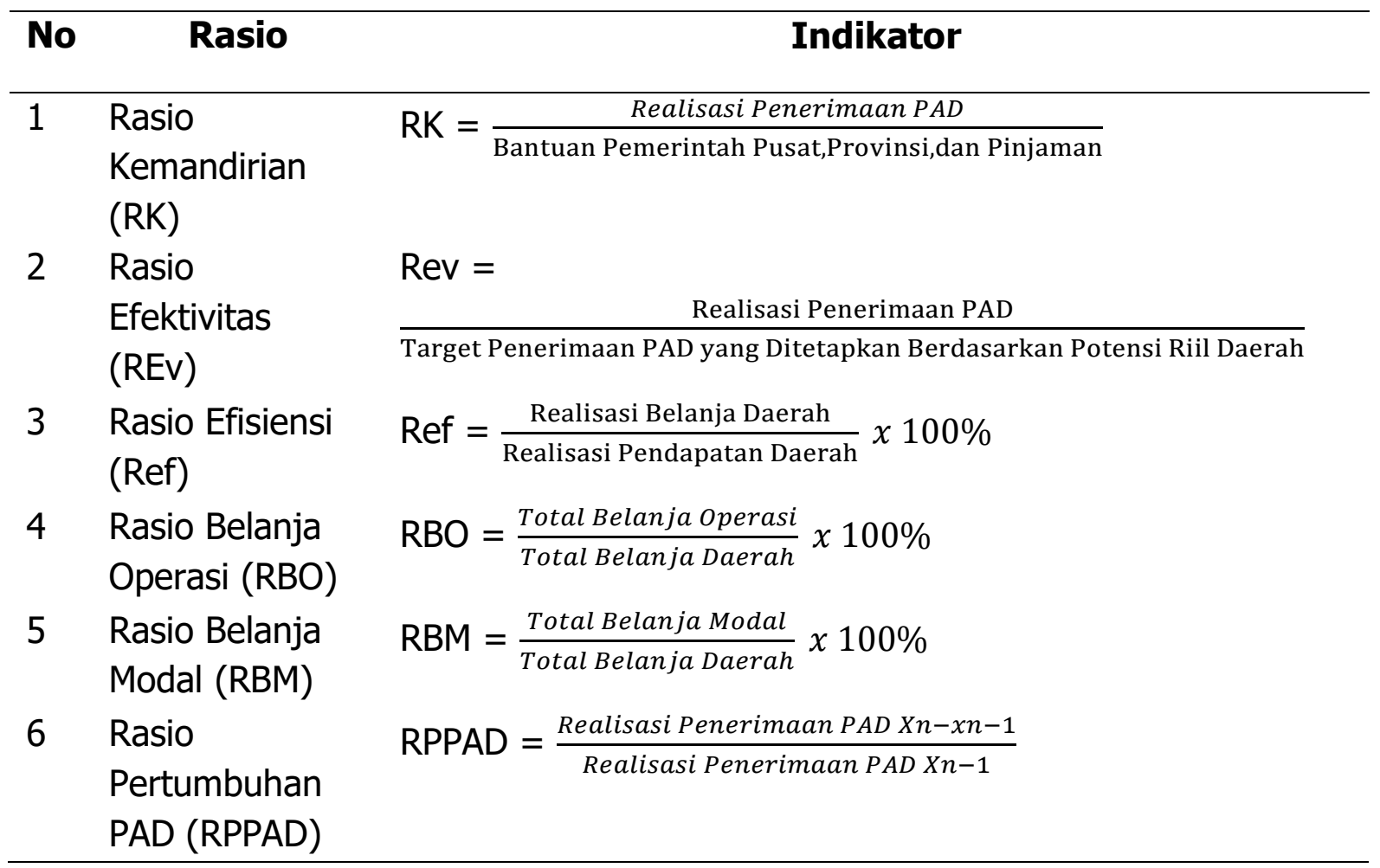

Sumber : Wibawa dan Ruslin, 2017

\section{Metode Analisis Data}

Analisis data diperlukan untuk menjelaskan hasil penelitian yang telah dilakukan.Dalam penelitian ini, penulis menggunakan metode deskriptif kuantitatif komparatif yaitu menggambarkan kinerja keuangan Pemerintah Daerah (kabupaten/kota) yang memperoleh Opini WTP di Provinsi Nusa Tenggara Barat tahun anggaran 2016, kemudian membandingkan hasil analisis tersebut. Alat analisis yang digunakan dalam penelitian ini adalah rasio 
keuangan. Analisis rasio keuangan digunakan untuk menganalisis kinerja keuangan pemerintah daerah yaitu dengan menghitung rasio keuangan dari pos-pos dalam Anggaran Pendapatan dan Belanja Daerah (APBD).

HASIL PENELITIAN DAN PEMBAHASAN

\section{Hasil Statistik Deskriptif}

Hasil pengujian statistic deskriptif ada di tabel 5 yaitu :

Tabel 5.

Statistik Deskriptif

\begin{tabular}{lcccc}
\hline \multicolumn{1}{c}{ Indikator } & Mean & Max & Min & $\begin{array}{c}\text { Standar } \\
\text { Devisiasi }\end{array}$ \\
\hline Rasio Kemandirian & 0.12 & 0.27 & 0.04 & 0.07 \\
Rasio Efektivitas & 1.01 & 1.29 & 0.87 & 0.13 \\
Rasio Efisiensi & 0.90 & 1.01 & 0.75 & 0.08 \\
Rasio Belanja Operasi & 0.72 & 0.81 & 0.53 & 0.09 \\
Rasio Belanja Modal & 0.26 & 0.37 & 0.19 & 0.07 \\
Rasio Pertumbuhan PAD & 0.13 & 0.28 & 0.01 & 0.10 \\
\hline
\end{tabular}

Sumber : Hasil pengolahan data excel 2017

Berdasarkan tabel 5 ada 6 indikator pengukuran kinerja keuangan pemerintah daerah yang terdiri dari kemandirian, efektifitas, efisiensi, belanja operasi, belanja modal, dan pertumbuhan PAD bagi Pemerintah Kabupaten/ Kota se- NTB yang beropini WTP terlihat bahwa a) rata-rata untuk rasio kemandirian rendah sekali yaitu hanya $12 \%$ b) rata-rata untuk rasio efektivitas 
Nurabiah : Analisis Perbandingan Kinerja Keuangan Pemerintah Daerah...

sudah efektif dimana di atas 1 atau $100 \%$ c) rata-rata untuk rasio efisiensi cukup efisien yaitu $90 \%$ d) rata-rata untuk rasio belanja operasi cukup besar yaitu $70 \%$ e) rata-rata untuk rasio belanja modal cukup tinggi yaitu $26 \%$ f) rata-rata rasio pertumbuhan PAD cukup rendah yaitu $13 \%$.

\section{Perbandingan Kinerja Keuangan Antar Pemerintah Daerah yang}

\section{Memperoleh WTP di Provinsi NTB}

\section{Perbandingan Rasio Kemandirian}

Rasio kemandirian adalah rasio yang menunjukan Pemerintah Daerah dalam membiayai sendiri kegiatan pemerintah, pembangunan pelayanan kepada masyarakat yang telah membayar pajak dan retribusi daerah sebagai sumber Pendapatan Asli Daerah dibandingkan dengan pendapatan daerah yang berasal dari sumber lain. Hasil olahan datanya ada di tabel 6 yaitu :

Tabel 6.

Perbandingan Rasio Kemandirian Daerah Tahun 2016

\begin{tabular}{ccc}
\hline Kabupaten/Kota & Kemandirian (\%) & Kriteria \\
\hline Mataram & $27 \%$ & Rendah \\
Lombok Utara & $20 \%$ & Rendah Sekali \\
Lombok Barat & $16 \%$ & Rendah Sekali \\
Lombok Tengah & $10 \%$ & Rendah Sekali \\
Lombok Timur & $12 \%$ & Rendah Sekali \\
Sumbawa & $10 \%$ & Rendah Sekali \\
Sumbawa Barat & $5 \%$ & Rendah Sekali \\
Dompu & $9 \%$ & Rendah Sekali \\
Kab. Bima & $8 \%$ & Rendah Sekali \\
Kota Bima & $4 \%$ & Rendah Sekali \\
\hline
\end{tabular}

Sumber : Hasil olahan data tahun 2017 
Pada tabel 6 terlihat dari 10 kabupaten/kota yang memperoleh WTP yang tingkat kemandirian rendah yaitu Kota Mataram sedangkan 9 kabupaten/kota lainnya terlihat bahwa tingkat kemandiriannya sangat rendah. Hal demikian mengindikasikan bahwa tingkat kemandirian keuangan Pemerintah Kabupaten/Kota di NTB cenderung rendah. Sehingga dapat disimpulkan ketergantungan akan bantuan dari pemerintah pusat semakin tinggi. Artinya bahwa peranan pemerintah pusat dalam memberikan bantuan kepada pemerintah daerah masih dominan. Hal ini dapat dilihat dari persentase rata-rata rasio kemandirian yang berada dikisaran 0-25\%. Rasio kemandirian yang masih rendah mengakibatkan kemampuan keuangan pemerintah daerah dalam membiayai pelaksanaan pemerintahan dan pembangunan masih sangat tergantung pada pemerintah pusat.

\section{Perbandingan Rasio Efektivitas}

Rasio Efektivitas menggambarkan seberapa efektif suatu daerah dalam merealisasikan PAD yang telah dianggarkan tersebut. Kinerja keuangan pemerintah daerah dikategorikan efektif apabila rasio lebih dari 1 atau $100 \%$. Hasil olahan datanya ada di tabel 7 yaitu : 
Nurabiah: Analisis Perbandingan Kinerja Keuangan Pemerintah Daerah...

Tabel 7.

Perbandingan Rasio Efektivitas Daerah Tahun 2016

\begin{tabular}{ccc}
\hline Kabupaten/Kota & Efektivitas (\%) & Kriteria \\
\hline Mataram & $103 \%$ & Sangat Efektif \\
Lombok Utara & $113 \%$ & Sangat Efektif \\
Lombok Barat & $96 \%$ & Cukup Efektif \\
Lombok Tengah & $105 \%$ & Sangat Efektif \\
Lombok Timur & $93 \%$ & Cukup Efektif \\
Sumbawa & $93 \%$ & Cukup Efektif \\
Sumbawa Barat & $129 \%$ & Sangat Efektif \\
Dompu & $105 \%$ & Sangat Efektif \\
Kab. Bima & $89 \%$ & Kurang Efektif \\
Kota Bima & $87 \%$ & Kurang Efektif
\end{tabular}

Sumber : Hasil olahan data tahun 2017

Pada tabel 7 terlihat dari 10 kabupaten/kota yang memperoleh WTP yang tingkat keefektifan dalam merealisasikan PAD ada tiga kategori yaitu kategori sangat efektif dimana ada 5 kabupaten/kota, kategori cukup efektif ada 3 kabupaten/kota dan kategori kurang efektif ada 2 kabupaten/kota. Hal demikian mengindikasikan bahwa tingkat keefektifan dalam merealisasikan PAD sudah cukup efektif. Namun, terdapat beberapa daerah yang masih belum memiliki rasio efektifitas yang ideal, dalam artian masih memiliki kinerja keuangan yang diklasifikasikan tidak efektif. Hal ini dapat dilihat pada Pemerintah Kabupaten dan Kota Bima yang memiliki rasio efektifitas yang 
termasuk klasifikasi kurang efektif untuk pemerintah daerah yang memperoleh Opini Wajar Tanpa Pengecualian.

\section{Perbandingan Rasio Efisiensi}

Rasio Efisiensi adalah rasio yang menggambarkan perbandingan antara realisasi pengeluaran (belanja daerah) dengan realisasi pendapatan daerah (Halim, 2007:234). Kinerja pemerintah daerah dapat dikategorikan efisien apabila rasio yang dicapai kurang dari satu atau dibawah 100\%. Semakin kecil rasio efisiensi berarti kinerja pemerintah daerah semakin baik. Hasil olahan datanya ada di tabel 8 yaitu :

\section{Tabel 8.}

\section{Perbandingan Rasio Efisiensi Daerah Tahun 2016}

\begin{tabular}{ccc}
\hline Kabupaten/Kota & Efisiensi (\%) & Kriteria \\
\hline Mataram & $95 \%$ & Kurang Efisien \\
Lombok Utara & $96 \%$ & Kurang Efisien \\
Lombok Barat & $88 \%$ & Cukup Efisien \\
Lombok Tengah & $84 \%$ & Cukup Efisien \\
Lombok Timur & $99 \%$ & Kurang Efisien \\
Sumbawa & $83 \%$ & Cukup Efisien \\
Sumbawa Barat & $75 \%$ & Efisien \\
Dompu & $96 \%$ & Kurang Efisien \\
Kab. Bima & $85 \%$ & Cukup Efisien \\
Kota Bima & $101 \%$ & Tidak Efisien
\end{tabular}

Sumber : Hasil olahan data tahun 2017

Pada tabel 8 terlihat dari 10 kabupaten/kota yang memperoleh WTP yang tingkat keefisiensi dalam keuangan daerah ada 4 kategori yaitu kategori efisien hanya ada 1 kabupaten, kategori cukup efisien ada 4 kabupaten, kategori kurang efisien ada 4 kabupaten/kota, dan kategori tidak efisien ada 1 
Nurabiah: Analisis Perbandingan Kinerja Keuangan Pemerintah Daerah...

kota. Hal demikian mengindikasikan bahwa tingkat efisien kabupaten/kota bervariasi. Dari hasil persentase tersebut menunjukkan bahwa hanya ada satu pemerintah daerah di Provinsi Nusa Tenggara Barat yang termasuk dalam klasifikasi efisien pada tahun anggaran 2016. Dalam artian pemerintah daerah di Provinsi NTB tahun anggaran 2016 rata-rata masih belum efisien dalam mengelola keuangan daerahnya.

\section{Perbandingan Rasio Belanja Operasi}

Rasio Belanja Operasi merupakan perbandingan antara total Belanja Operasi dengan Total Belanja Daerah. Rasio ini menginformasikan kepada pembaca laporan mengenai porsi belanja daerah yang dialokasikan untuk Belanja Operasi. Belanja Operasi merupakan belanja yang manfaatnya habis dikonsumsi dalam satu tahun anggaran, sehingga sifatnya jangka pendek dan dalam hal tertentu sifatnya rutin atau berulang. Hasil olahan datanya ada di tabel 9 yaitu : 


\section{Tabel 9}

\section{Perbandingan Rasio Belanja Operasi Daerah Tahun 2016}

\begin{tabular}{cc}
\hline Kabupaten/Kota & Belanja Operasi \\
\hline Mataram & $75 \%$ \\
Lombok Utara & $53 \%$ \\
Lombok Barat & $78 \%$ \\
Lombok Tengah & $79 \%$ \\
Lombok Timur & $81 \%$ \\
Sumbawa & $77 \%$ \\
Sumbawa Barat & $62 \%$ \\
Dompu & $69 \%$ \\
Kab. Bima & $77 \%$ \\
Kota Bima & $72 \%$ \\
\hline
\end{tabular}

Sumber : Hasil olahan data tahun 2017

Pada tabel 9 terlihat dari 10 kabupaten/kota yang memperoleh WTP yang tingkat belanja operasi daerah berbeda-beda. Hal demikian mengindikasikan bahwa tingkat belanja operasi kabupaten/kota bervariasi. Pada umumya proporsi Belanja Operasi mendominasi total belanja daerah, yaitu antara $60-90 \%$. Pemerintah daerah dengan tingkat pendapatan yang tinggi cenderung memiliki porsi belanja operasi yang lebih tinggi dibandingkan pemerintah daerah yang tingkat pendapatannya rendah (Mahmudi, 2010:164). Kalau dilihat pada tabel 9 ada kabupaten yaitu kabupaten Lombok Utara yang belanja operasinya masih dibawah $60 \%$ yaitu sebesar $53 \%$. Dan yang paling tinggi belanja operasi yaitu kabupaten Lombok Timur yaitu sebesar $81 \%$. Belanja operasi perlu ditekan oleh setiap pemerintah daerah guna meningkatkan alokasi belanja modal demi kepentingan masyarakat pada umumnya. 
Nurabiah: Analisis Perbandingan Kinerja Keuangan Pemerintah Daerah...

\section{Perbandingan Rasio Belanja Modal}

Rasio Belanja Modal merupakan perbandingan antara total realisasi belanja modal dengan total belanja daerah. Berdasarkan rasio ini, pembaca laporan dapat mengetahui porsi belanja daerah yang dialokasikan untuk investasi dengan bentuk belanja modal pada tahun anggaran bersangkutan. Belanja modal memberikan manfaat jangka menengah dan panjang juga bersifat rutin. Pada umumnya proporsi belanja modal dengan belanja daerah antara 5-20\% (Mahmudi 2010:164). Hasil olahan datanya ada di tabel 10 yaitu:

Tabel 10

Perbandingan Rasio Belanja Modal Daerah Tahun 2016

\begin{tabular}{cc}
\hline Kabupaten/Kota & Belanja Operasi \\
\hline Mataram & $25 \%$ \\
Lombok Utara & $37 \%$ \\
Lombok Barat & $22 \%$ \\
Lombok Tengah & $21 \%$ \\
Lombok Timur & $19 \%$ \\
Sumbawa & $23 \%$ \\
Sumbawa Barat & $37 \%$ \\
Dompu & $20 \%$ \\
Kab. Bima & $23 \%$ \\
Kota Bima & $28 \%$
\end{tabular}

Sumber : Hasil olahan data tahun 2017

Pada tabel 10 terlihat dari 10 kabupaten/kota yang memperoleh WTP yang tingkat belanja modal daerah berbeda-beda. Hal demikian 
mengindikasikan bahwa tingkat belanja modal kabupaten/kota bervariasi. Hal ini dapat dilihat pada persentase belanja modal yang masih jauh di bawah $50 \%$ dan jauh berada dibawah persentase belanja operasi. Rendahnya belanja modal tiap tahun, semestinya menjadi perhatian bagi setiap pemerintah daerah di Provinsi Nusa Tenggara Barat.

\section{Perbandingan Rasio Pertumbuhan PAD}

Rasio pertumbuhan digunakan untuk mengukur seberapa besar kemampuan pemerintah daerah dalam mempertahankan dan meningkatkan keberhasilannya yang telah dicapai dari periode ke periode berikutnya (Mahmudi 2010:138). Hasil olahan datanya ada di tabel 11 yaitu :

\section{Tabel 11}

Perbandingan Rasio Pertumbuhan PAD Daerah Tahun 2016

\begin{tabular}{cc}
\hline Kabupaten/Kota & Belanja Operasi \\
\hline Mataram & $28 \%$ \\
Lombok Utara & $26 \%$ \\
Lombok Barat & $17 \%$ \\
Lombok Tengah & $4 \%$ \\
Lombok Timur & $8 \%$ \\
Sumbawa & $1 \%$ \\
Sumbawa Barat & $16 \%$ \\
Dompu & $18 \%$ \\
Kab. Bima & $13 \%$ \\
Kota Bima & $1 \%$
\end{tabular}

Sumber : Hasil olahan data tahun 2017 
Nurabiah: Analisis Perbandingan Kinerja Keuangan Pemerintah Daerah...

Pada tabel 11 terlihat dari 10 kabupaten/kota yang memperoleh WTP yang tingkat pertumbuhan PAD daerah berbeda-beda. Hal demikian mengindikasikan bahwa tingkat pertumbuhan PAD kabupaten/kota bervariasi. Dari beberapa kabupaten/kota terlihat pertumbuhan PADnya masih ada yang dibawah $10 \%$ yaitu 2 kabupaten/kota sebesar 1\%, 1 kabupaten yang $4 \%$ dan 1 kabupaten yang $8 \%$. Rasio pertumbuhan PAD yang lebih tinggi menunjukkan kemampuan daerah yang lebih baik dalam memperoleh PAD dan pertumbuhan APBD yang semakin besar maka rasio ini semakin baik.

\section{SIMPULAN}

\section{Kesimpulan}

Berdasarkan hasil analisis, dapat ditarik beberapa kesimpulan terkait kinerja keuangan pemerintah daerah yang memperoleh Opini Wajar Tanpa Pengecualian (WTP) sebagai berikut:

1. Tingkat kemandirian keuangan daerah beberapa kabupaten/kota yang ada di Provinsi Nusa Tenggara Barat yang memperoleh Opini Wajar Tanpa Pengecualian (WTP) cenderung rendah, rasio kemandirian yang masih rendah mengakibatkan kemampuan keuangan pemerintah daerah dalam membiayai pelaksanaan pemerintahan dan pembangunan masih sangat tergantung pada pemerintah pusat dan artinya peranan pemerintah pusat dalam memberikan bantuan kepada pemerintah daerah masih dominan. 
2. Tingkat efektifitas keuangan daerah beberapa kabupaten/kota yang ada di Provinsi Nusa Tenggara Barat yang memperoleh Opini Wajar Tanpa Pengecualian (WTP) cukup efektif. Namun, terdapat beberapa daerah yang masih belum memiliki rasio efektifitas yang ideal, dalam artian masih memiliki kinerja keuangan yang diklasifikasikan tidak efektif.

3. Tingkat efisiensi keuangan daerah beberapa kabupaten/kota yang ada di Provinsi Nusa Tenggara Barat yang memperoleh Opini Wajar Tanpa Pengecualian (WTP) belum efisien dalam mengelola keuangan daerahnya, dimana hanya ada satu pemerintah daerah yang termasuk dalam klasifikasi efisien pada tahun anggaran 2016.

4. Tingkat belanja operasi keuangan daerah beberapa kabupaten/kota yang ada di Provinsi Nusa Tenggara Barat yang memperoleh Opini Wajar Tanpa Pengecualian (WTP) masih cukup tinggi yaitu diatas $70 \%$, walaupun ada satu kabupaten yang dibawah $60 \%$. Belanja operasi perlu ditekan oleh setiap pemerintah daerah guna meningkatkan alokasi belanja modal demi kepentingan masyarakat pada umumnya.

5. Tingkat belanja modal keuangan daerah beberapa kabupaten/kota yang ada di Provinsi Nusa Tenggara Barat yang memperoleh Opini Wajar Tanpa Pengecualian (WTP) masih rendah. Hal ini dapat dilihat pada persentase 
Nurabiah: Analisis Perbandingan Kinerja Keuangan Pemerintah Daerah...

belanja modal yang masih jauh di bawah $50 \%$ dan jauh berada dibawah persentase belanja operasi.

6. Tingkat pertumbuhan Pendapatan Asli Daerah (PAD) keuangan daerah beberapa kabupaten/kota yang ada di Provinsi Nusa Tenggara Barat yang memperoleh Opini Wajar Tanpa Pengecualian (WTP) bervariasi, dimana ada beberapa kabupaten/kota yang rasionya di bawah $10 \%$ dan yang lainnya sudah di atas $10 \%$.

\section{KETERBATASAN DAN SARAN}

Penelitian ini tidak terlepas dari beberapa keterbatasan antara lain :

1. Indikator pengukuran kinerja keuangan yang digunakan pada penelitian ini terbatas pada rasio kemandirian, rasio efektifitas, rasio efisiensi, rasio pertumbuhan dan rasio keselaran. Penelitian selanjutnya diharapkan dapat memperluas indikator pengukuran dengan menambahkan pengukuranpengukuran lainnya, sehingga hasil penelitian akan lebih baik lagi.

2. Hanya terbatas pada satu tahun dan satu provinsi, penelitian selanjutnya diharapkan dapat melakukan penelitian beberapa tahun dan di seluruh provinsi yang ada di Indonesia. 


\section{DAFTAR PUSTAKA}

Fattah, Sanusi \& Irman. 2010. Analisis ketergantungan fiskal pemerintah daerah di Provinsi sulawesi selatan pada era otonomi daerah. Wordpress Fakultas Ekonomi Universitas Hasanuddin. Makasar.

Firmanzah. 2012. Akuntabilitas Penggunaan Anggaran Negara. (http://www.setkab.go.id), diakses pada 9 April 2018.

Hakiki. 2017. Analisis Perbandingan Kinerja Keuangan Pemerintah Daerah Kabupaten/Kota Dengan Opini Wajar Tanpa Pengecualian (WTP) Dan $\begin{array}{llll}\text { Non } & \text { WTP } & \text { Berbasis } & \text { Value }\end{array}$ Moneydi Provinsi Lampung Tahun 2011-2015. Skripsi Fakultas Ekonomi dan Bisnis Universitas Lampung. Unpublish

Halim, Abdul. 2004. Manajemen Keuangan Daerah. Jakarta: Salemba Empat. Khairudin. 2013. Does Financial Performance Of Local Government Influence On The Audit Agency Opinion?. Jurnal Akuntansi \& Keuangan Vol. 4, No. 1, Maret.

Khusaini, Mohammad ,2006. Ekonomi Publik : Desentralisasi Fiskal dan Pembangunan Daerah. BPFE Unibraw, Malang.

Mahmudi. (2007). Manajemen Kinerja Keuangan Sektor Publik. Yogyakarta : UPP STIM YKPN. 
Nurabiah: Analisis Perbandingan Kinerja Keuangan Pemerintah Daerah...

Patra dan Ramlah. 2017. Analisis Kinerja Pengolahan Keuangan Daerah Dan Hubungannya Dengan Opini Laporan Pemeriksaan Bpk Atas Laporan Keuangan Pemerintah Daerah. Jurnal Akuntansi. Vol. 03 No. 01 Februari.

Sugiyono. 2014. Metode Penelitian Bisnis. Bandung: Indonesia. Alfabeta.

Susantih. 2009. Analisis Pengaruh Pendapatan Asli Daerah. Jurnal Analisis Perbandingan Kinerja Keuangan Pemerintah Daerah. Palembang.

Tarmizi, Rosmiaty; Khairudin; dan Jayadi, Ayu. 2014. Analisis Kinerja Keuangan Pemerintah Daerah Kota Bandar Lampung Sebelum Dan Setelah Memperoleh Opini WTP. Jurnal Akuntansi \& Keuangan Vol. 5, No. 2, September

Taufik. 2017. Analisis Perbandingan Kinerja Keuangan Pemerintah Kabupaten Kota Se-Sumatera. Jurnal Ilmiah Gema Ekonomi Vol. 7, No. 1 Februari 2017 Hal. 993-1012.

Wibawa, dkk. 2017. Analisis Perbandingan Kinerja Keuangan Pemerintah Daerah yang Memperoleh Opini Wajar Tanpa Pengecualian (WTP) dengan Opini Wajar Dengan Pengecualian (WDP) di Provinsi Sulawesi Tenggara. SNA XX Jember. 